\title{
Penerapan Metode User Centered Design Untuk Mengembangkan E-Learning Universitas Jember Berbasis Mobile
}

\author{
Fahrobby Adnan*, Muhammad Huda Muttaqin**, Tio Dharmawan *** \\ *Fakultas Ilmu Komputer, Universitas Jember \\ **Fakultas Ilmu Komputer, Universitas Jember \\ *** Fakultas Ilmu Komputer, Universitas Jember \\ *fahrobby@unej.ac.id**huda@students.unej.ac.id***tio.pssi@unej.ac.id
}

\begin{abstract}
ABSTRAK
Aspek usability atau daya guna mengacu pada sudut pandang pengguna saat menggunakan dan memanfaatkan suatu produk. Penggunaan metode yang kurang tepat pada pengembangan desain suatu aplikasi akan berdampak pada besarnya jumlah permintaan untuk memodifikasi produk setelah produk selesai dikerjakan. Masalah pemilihan metode yang kurang tepat pada pengembangan desain biasanya terjadi pada aplikasi berbasis Graphical User Interface (GUI), E-commerce websites, mobile services, dan juga teknologi dalam bidang pendidikan yaitu e-learning. E-learning merupakan salah satu teknologi yang berkembang pesat sebagai sistem pembelajaran jarak jauh yang memberikan ragam solusi di mana Internet sebagai medianya. Didukung dengan memanfaatkan kehadiran perkembangan teknologi bernama smartphone juga dapat dimanfaatkan untuk mempermudah proses pembelajaran. Dengan adanya smartphone, pelajar akan lebih mudah mengakses materi pembelajaran, dan pengajar juga lebih mudah dalam membagikan materi yang akan diajarkan. Untuk mendukung usaha memperoleh tingkat kepuasan pengguna tanpa meninggalkan tujuan khusus dari pembuatan aplikasi itu sendiri dapat diterapkan sebuah metode user centered design (UCD). UCD merupakan metode yang mengacu pendekatan kepada keinginan user. Dengan penerapan metode ini user akan merasa puas dan nyaman saat berinteraksi dengan sistem. Berdasarkan pada konsep dari metode UCD dan permasalahan yang terjadi pada e-learning khususnya aplikasi E-Learning Universitas Jember maka dapat dilihat bahwa metode UCD cocok untuk diterapkan dalam pengembangan aplikasi e-learning Universitas Jember berbasis mobile (M-Learning) dengan tujuan untuk lebih memudahkan mahasiswa dan dosen dalam proses pembelajaran di Universitas Jember. Penelitian ini dilaksanakan dalam 3 tahap yaitu tahap pengumpulan data, tahap analisis, dan tahap pengembangan sistem. Tahap pengumpulan data yang terdiri dari studi literatur, dan kuesioner. Tahap analisis dilakukan dengan mengolah data hasil kuesioner dan melakukan usability testing. Tahap pengembangan dilakukan dengan membangun aplikasi e-learning berbasis mobile. Hasil dari penelitian ini adalah sebuah aplikasi M-Learning Universitas jember.
\end{abstract}

Kata kunci: User Centered Design (UCD), Usability, E-learning

\section{Pendahuluan}

Aspek usability atau daya guna merupakan kajian penelitian Interaksi Manusia dan Komputer (IMK) yang mengacu pada sudut pandang pengguna saat menggunakan dan memanfaatkan suatu produk. Penggunaan metode yang kurang tepat pada pengembangan desain suatu aplikasi akan berdampak pada besarnya jumlah permintaan untuk memodifikasi produk setelah produk selesai dikerjakan. Permintaan tersebut muncul karena ketika menggunakan sebuah aplikasi, pengguna akan memberikan penilaian tersendiri, merasa kecewa dan memutuskan bahwa aplikasi tersebut tidak layak untuk dikunjungi. Hal itu pula yang menyebabkan banyak aplikasi yang ditinggalkan pengguna karena gagalnya pencapaian pada tujuan awal. Kerugian lainnya adalah keuntungan aplikasi tersebut akan menurun dan aplikasi tidak dapat mempertahankan eksistensinya atau dengan kata lain diberhentikan penggunaannya.

Masalah pemilihan metode yang kurang tepat pada pengembangan desain biasanya terjadi pada aplikasi berbasis Graphical User Interface (GUI), E-commerce websites, mobile services, dan juga teknologi dalam bidang pendidikan yaitu e-learning. E-learning merupakan salah satu teknologi yang berkembang pesat sebagai sistem pembelajaran jarak jauh yang memberikan ragam solusi dimana internet sebagai medianya[1]. Didukung dengan memanfaatkan kehadiran perkembangan teknologi bernama smartphone juga dapat dimanfaatkan untuk mempermudah proses pembelajaran[2]. Dengan adanya smartphone, pelajar akan lebih mudah mengakses materi pembelajaran, dan pengajar juga lebih mudah dalam membagikan materi yang akan diajarkan[3]. 
Untuk mendukung usaha memperoleh tingkat kepuasan pengguna tanpa meninggalkan tujuan khusus dari pembuatan aplikasi itu sendiri dapat diterapkan sebuah metode User Centered Design (UCD). UCD merupakan metode yang mengacu pendekatan kepada keinginan user/pengguna. Dengan penerapan metode ini, user akan merasa nyaman saat berinteraksi dengan sistem sehingga informasi yang disediakan dapat tersampaikan dengan baik.

Dari uraian diatas, penulis tertarik untuk mengembangkan sebuah sistem yang dapat memberikan kenyamanan bagi penggunanya. Berdasarkan pada konsep dari metode UCD dan permasalahan yang terjadi pada e-learning khususnya aplikasi E-Learning Universitas Jember maka penulis tertarik untuk mengembangkan aplikasi e-learning Universitas Jember berbasis mobile (M-Learning) dengan menerapkan metode UCD dengan tujuan untuk lebih memudahkan mahasiswa dan dosen dalam proses pembelajaran di Universitas Jember.

\section{Metode Penelitian}

Penelitian ini dilaksanakan untuk mengetahui kemanfaatan (Usability) pada E-learning Universitas Jember. Penelitian ini merupakan penelitian survei, yaitu penelitian yang mengambil sampel secara langsung dari populasi dengan menyebarkan kuisioner kepada subjek penelitian. Subjek penelitian ini adalah mahasiswa dan dosen Universitas Jember.

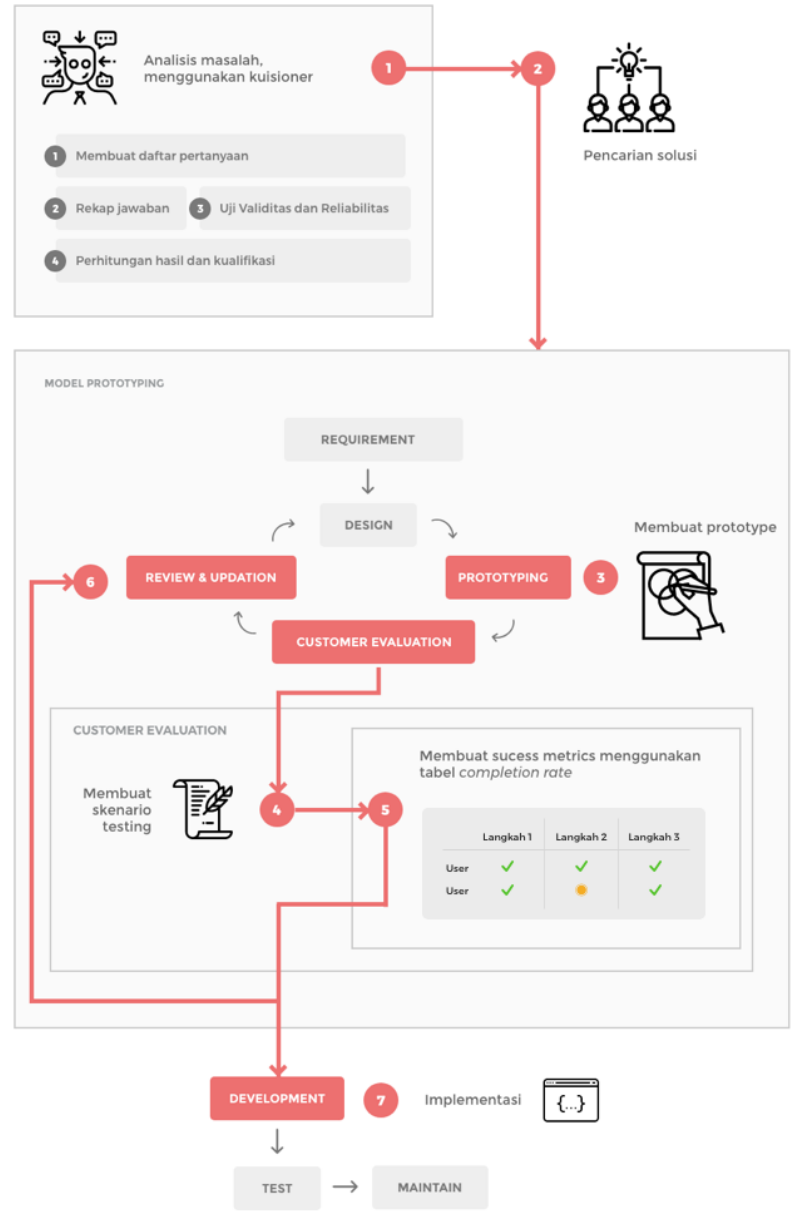

Gambar 1 Diagram Alur Penelitian

Gambar 1 menjelaskan tentang alur penelitian yang menerapkan metode User Centered Design (UCD) dan menggunakan system development life cycle (SDLC) model prototyping dalam proses pengembangan aplikasi. Teknik pengumpulan data yang akan dilakukan pada penelitian ini adalah sebagai berikut:

\section{Analisis Masalah}

Menganalisis masalah yang dihadapi pengguna ketika menggunakan E-Learning Universitas Jember menggunakan kuesioner yang telah diuji validitas dan reliabilitas[4]. Masalah yang dihadapi pengguna berkaitan dengan usability pada E-Learning Universitas Jember dan target penelitian atau responden adalah mahasiswa dan dosen Universitas Jember. Responden dalam penelitian diklasifikasikan dengan pengelompokan level pengguna E-Learning Universitas Jember menjadi 3 kelompok yaitu level awam, aktif, dan terampil yang terdiri dari 2 jenis pengguna yaitu mahasiswa dan dosen. Responden level awam 
ialah pengguna yang tidak mengetahui dan tidak menggunakan semua fitur pada E-Learning. Responden level aktif ialah pengguna yang mengetahui seluruh fitur E-Learning tetapi tidak menggunakan seluruh fitur tersebut. Sedangkan level terampil ialah pengguna yang mengetahui dan menggunakan seluruh fitur pada E-Learning[5]. Detail klasifikasi dapat dilihat pada Tabel 1.

Tabel 1 Klasifikasi Responden

\begin{tabular}{|l|c|l|}
\hline \multicolumn{1}{|c|}{ Level } & Banyak & \multicolumn{1}{c|}{ Klasifikasi } \\
\hline Awam & 15 & $\begin{array}{l}\text { Mahasiswa / dosen yang tidak } \\
\text { mengetahui dan tidak } \\
\text { menggunakan semua fitur }\end{array}$ \\
\hline Aktif & 15 & $\begin{array}{l}\text { Mahasiswa / dosen yang } \\
\text { mengetahui tetapi tidak } \\
\text { menggunakan semua fitur }\end{array}$ \\
\hline Terampil & 15 & $\begin{array}{l}\text { Mahasiswa / dosen yang } \\
\text { mengetahui dan menggunakan } \\
\text { semua fitur }\end{array}$ \\
\hline
\end{tabular}

\section{Pencarian Solusi}

Menganalisa hasil kuesioner menggunakan analisis deskriptif sehingga ditemukan nilai mean dari perhitungan hasil kuesioner. Aspek yang dinilai adalah 5 variabel usability yaitu learnability, efficiency, memorability, error, dan satisfaction[6]. Rentang nilai mean tiap variabel dikelompokkan menjadi 4 kategori yang dapat dilihat pada Tabel 2.

Tabel 2 Pengelompokan Nilai Kategori

\begin{tabular}{|c|c|}
\hline Nilai & Kualifikasi \\
\hline $3,01-4,00$ & Sangat baik \\
\hline $2,01-3,00$ & Baik \\
\hline $1,01-2,00$ & Kurang baik \\
\hline $0,01-1,00$ & Sangat kurang baik \\
\hline
\end{tabular}

Variabel usability yang memiliki nilai kualifikasi kurang baik atau sangat kurang baik menjadi poin yang harus diperbaiki dalam merancang aplikasi Mobile Learning (M-Learning) Universitas Jember menggunakan metode User Centered Design. Pencarian solusi dalam hal ini adalah melihat dari tiap variabel yang sebelumnya telah dijadikan poin perbaikan, kemudian dilihat indikator yang terdapat dalam variabel tersebut[7][8]. Indikator dalam variabel dapat menunjukkan apa yang harus diperbaiki jika ditemukan nilai kualifikasi yang kurang baik dalam variabel tersebut.

\section{Membuat Prototype}

Membuat prototype aplikasi M-Learning yang dapat menutupi kekurangan pada setiap variabel memiliki nilai kurang baik dalam penilaian hasil kuesioner. Prototype dibuat menggunakan software Adobe Experience Design dimana hasil output berupa gambar namun sudah dapat mewakili seluruh tampilan atau user interface dari aplikasi M-Learning yang akan dibuat. Prototype yang dibuat akan diberikan kepada tester untuk dilakukan pengujian terhadap setiap fitur yang ada didalam aplikasi sesuai dengan perannya masing-masing. Pengujian prototype dilakukan kepada 6 tester yang dibagi menjadi dua kelompok peran, yaitu 3 dosen dan 3 mahasiswa.

4. Membuat Skenario Pengujian

Skenario pengujian digunakan sebagai petunjuk bagi pengguna atau tester dalam melakukan pengujian terhadap prototype yang telah dibuat sebelumnya. Tester melakukan tugas yang diberikan dengan menjalankan prototype sesuai dengan skenario yang diperintahkan.

\section{Membuat Success Metrics}

Membuat success metrics yang berisi penilaian dari perilaku pengguna pada saat menjalankan tahap pengujian prototype menggunakan tabel completion rate. Pengujian dilakukan pada setiap fitur yang ada di sistem melalui prototype, dan dinilai berdasarkan pemahaman pengguna atau tester dalam menyelesaikan tiap langkah dalam suatu fitur sesuai dengan skenario pengujian yang diberikan.

Penilaian terhadap pengguna menggunakan 3 nilai, yaitu lancar (v) jika pengguna lancar dalam melewati setiap langkah tanpa mengalami kesulitan, cukup lama (o) jika pengguna sedikit kesulitan dalam menyelesaikan suatu langkah, dan gagal (x) jika pengguna kebingungan dan tidak bisa melanjutkan ke langkah selanjutnya.

6. Melakukan Evaluasi Hasil Pengujian

Melakukan evaluasi hasil pengujian dengan cara melihat hasil dari tabel completion rate. Ketika hasil yang ditemukan kurang dari 50\% pengguna atau tester yang mengalami kesulitan dalam menyelesaikan suatu 
tugas yang diberikan, maka perlu dilakukan perbaikan prototype pada fitur yang memiliki penilaian kurang baik. Hal ini dilakukan hingga ditemukan hasil evaluasi yang baik, yaitu lebih dari 50\% tester tidak kesulitan dalam menyelesaikan setiap perintah yang diberikan sesuai dengan perannya masing-masing.

\section{Implementasi}

Setelah ditemukan persentase hasil evaluasi yang baik, maka prototype yang telah dibuat dapat di implementasikan ke dalam bahasa pemrograman. Implementasi prototype ditulis dalam dua bahasa pemrograman. Bahasa pemrograman PHP menggunakan framework Laravel yang dibagi menjadi 2 kelas yaitu kelas model dan controller digunakan untuk mengambil data dari database, kemudian bahasa pemrograman Javascript menggunakan framework Ionic yang terdiri dari 2 kelas yaitu provider dan view digunakan untuk menampilkan data yang sebelumnya telah diambil ke dalam di aplikasi M-Learning.

8. Tahapan Pengujian Sistem

Pengujian aplikasi dilakukan dengan 2 cara yaitu:

a. White Box Testing merupakan cara pengujian dengan melihat modul yang telah dibuat dengan program yang ada. Pengujian white box menggunakan Cyclomatic Complexity $(C C)$ yang merupakan alat ukur untuk mengindikasi konpleksitas dari program dengan cara menelusuri nomor dari jalur yang independen melalui source code program. Rumus CC dapat dilihat pada rumus 1.1.

$$
\text { a. } V(G)=(E-N)+2
$$

b. Keterangan :

c. $\mathrm{V}(\mathrm{G})=$ Cyclomatic Complexity

d. $\mathrm{E}=$ Edge

e. $\mathrm{N}=$ Node

b. Black Box Testing merupakan cara pengujian perangkat lunak yang memeriksa fungsionalitas dari aplikasi yang berkaitan dengan struktur internal kerja. Pengujian dilaksanakan dengan menjalankan program secara langsung dan menganalisis input dan output yang dihasilkan aplikasi. Pengujian black box dilakukan oleh user yang mengoperasikan aplikasi.

\section{Hasil dan Pembahasan}

Dalam suatu penelitian, setiap variabel baik dependen dan independen biasanya memiliki beberapa indikator. Indikator tersebut kemudian dikonversikan menjadi berbagai pertanyaan atau pernyataan yang digunakan dalam kuisioner. Tabel 3 menjelaskan indikator-indikator yang digunakan dalam penelitian ini[9].

Tabel 3 Pemetaan Indikator

\begin{tabular}{|l|l|}
\hline \multirow{2}{*}{ 1. Learnability } & Easy to understand \\
\cline { 2 - 2 } & Easy to look for specific information \\
\cline { 2 - 2 } & $\begin{array}{l}\text { Easy to identify navigational } \\
\text { mechanism }\end{array}$ \\
\hline \multirow{2}{*}{ 2. Efficiency } & Easy to reach quickly \\
\cline { 2 - 2 } & Easy to navigate \\
\hline \multirow{2}{*}{ 3. Memorability } & Easy to remember \\
\cline { 2 - 2 } & Easy to reestablish \\
\hline \multirow{2}{*}{ 4. Error } & Few numbers of error detected \\
\cline { 2 - 2 } & Easy to fix \\
\hline \multirow{2}{*}{ 5. Satisfaction } & System pleasant to use \\
\cline { 2 - 2 } & Comfort to use \\
\hline
\end{tabular}

Dari variabel dan indikator tersebut kemudian dijabarkan menjadi 15 lalu dilakukan uji validitas dan reliabilitas tiap poin pertanyaan menggunakan SPSS. Kuesioner yang telah valid akan disebarkan kepada seluruh responden yang tertera pada Tabel 1. Kategori nilai hasil perhitungan yang dapat dimasukkan dalam statistik deskriptif adalah mean[10]. Nilai tersebut menggambarkan tingkat kecenderungan atau persetujuan user secara keseluruhan terkait pernyataan yang tertera dalam kuisioner. Tingkat kepuasan dikelompokkan menjadi 4 kategori yang dapat dilihat pada Tabel 4.

Tabel 4 Pengelompokan Kategori

\begin{tabular}{|c|c|}
\hline Nilai & Kualifikasi \\
\hline $3,01-4,00$ & Sangat baik (SB) \\
\hline $2,01-3,00$ & Baik (B) \\
\hline $1,01-2,00$ & Kurang baik (KB) \\
\hline $0,01-1,00$ & Sangat kurang baik (SKB) \\
\hline
\end{tabular}


Hasil perhitungan nilai mean dan kualifikasi kategori pada 5 variabel usability dapat dilihat pada tabel 5. Tabel 5 Nilai Mean dan Hasil Kualifikasi

\begin{tabular}{|l|c|c|c|}
\hline \multicolumn{1}{|c|}{ Variabel } & Jumlah & Mean & Kualifikasi \\
\hline Learnability & 45 & 1.92222222 & $\mathrm{~KB}$ \\
\hline Efficiency & 45 & 1.93333333 & $\mathrm{~KB}$ \\
\hline Memorability & 45 & 1.93888889 & $\mathrm{~KB}$ \\
\hline Error & 45 & 2.23888889 & $\mathrm{~B}$ \\
\hline Satisfaction & 45 & 2.36666667 & $\mathrm{~B}$ \\
\hline
\end{tabular}

Dari hasil ini dapat ditarik kesimpulan bahwa E-learning Universitas Jember memiliki nilai kualifikasi yang kurang baik pada 3 variabel berdasarkan usability testing. Sehingga perlu adanya peningkatan kualitas dari E-learning Universitas Jember agar menjadi lebih baik dan nyaman digunakan oleh pengguna.

Setelah dilakukan pengujian prototype, ditemukan hasil yang menunjukkan bahwa pada fitur lihat rincian pengumuman yang dilakukan oleh tester dosen, terdapat 2 tester yang cukup lama dalam menyelesaikan tugas dan terdapat 1 tester yang mengalami kesulitan sehingga tidak dapat melanjutkan ke langkah berikutnya. Tabel completion rate untuk fitur lihat rincian pengumuman oleh tester dosen dapat dilihat pada Tabel 6 dan untuk mahasiswa pada Tabel 7.

Tabel 6 Completion Rate Fitur Lihat Rincian Pengumuman tester Dosen

\begin{tabular}{|c|c|c|}
\hline \multicolumn{2}{|l|}{ Peran : Dosen } \\
\hline \multirow{2}{*}{ Fitur : Lihat Rincian Pengumuman } \\
\hline \multirow{2}{*}{ Status } & Langkah 1 & Langkah 2 \\
\cline { 2 - 3 } & $\begin{array}{c}\text { Klik menu } \\
\text { Pengumuman }\end{array}$ & Pilih pengumuman \\
\hline Tester 1 & $\mathrm{o}$ & $\mathrm{v}$ \\
\hline Tester 2 & $\mathrm{o}$ & $\mathrm{v}$ \\
\hline Tester 3 & $\mathrm{x}$ & - \\
\hline
\end{tabular}

Tabel 7 Completion Rate Fitur Lihat Rincian Pengumuman tester Mahasiswa

\begin{tabular}{|c|c|c|}
\hline \multicolumn{2}{|l|}{ Peran : Dosen } \\
\hline \multirow{2}{*}{ Fitur : Lihat Rincian Pengumuman } \\
\hline Status & Langkah 1 & Langkah 2 \\
\cline { 2 - 3 } & $\begin{array}{c}\text { Klik menu } \\
\text { Pengumuman }\end{array}$ & Pilih pengumuman \\
\hline Tester 1 & $\mathrm{o}$ & $\mathrm{v}$ \\
\hline Tester 2 & $\mathrm{o}$ & $\mathrm{v}$ \\
\hline Tester 3 & $\mathrm{v}$ & $\mathrm{v}$ \\
\hline
\end{tabular}

Dari hasil pengujian pertama dapat disimpulkan bahwa pada langkah 1 di fitur lihat rincian pengumuman hanya ada 1 tester yang dapat menyelesaikan tugas dengan mudah sehingga perlu dilakukan perbaikan pada langkah 1 fitur lihat rincian pengumuman[11]. Langkah 1 untuk fitur lihat rincian pengumuman adalah klik ikon pengumuman yang terdapat pada menu bawah halaman beranda.

Setelah dilakukan perbaikan prototype pada langkah 1 fitur lihat rincian pengumuman, dilakukan pengujian prototype yang kedua kepada semua tester. Pada pengujian prototype yang kedua ditemukan hasil yang baik pada fitur yang telah diperbaiki, yaitu fitur lihat rincian pengumuman dengan menambahkan nama menu Pengumuman pada menu sidebar sehingga terlihat lebih jelas dan lebih mudah dipahami daripada hanya berupa menu ikon seperti pada prototype yang pertama. Tampilan prototype untuk fitur lihat rincian pengumuman sebelum dan sesudah diperbaiki dapat dilihat pada Gambar 2. 


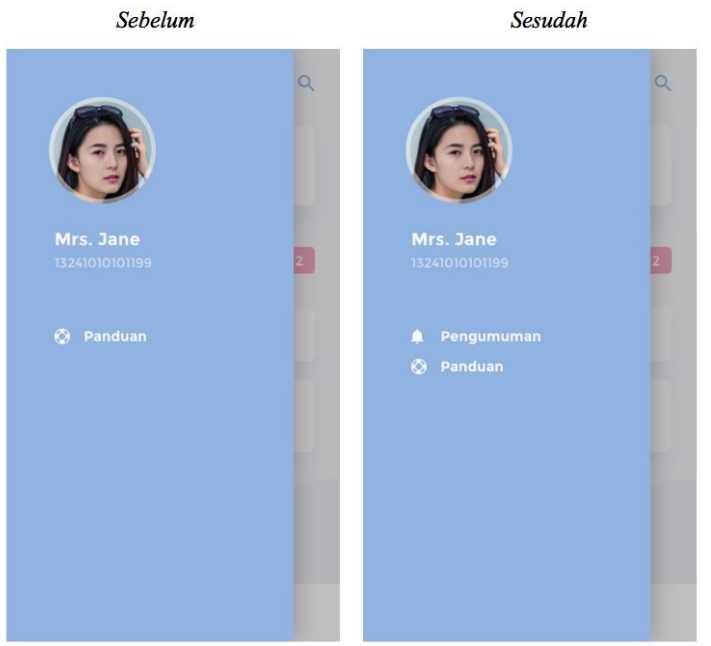

Gambar 2 Tampilan M-Learning sebelum dan sesudah di perbaiki

Aplikasi M-Learning memiliki beberapa fitur yang dapat diakses oleh 2 user, yaitu dosen, dan mahasiswa.

Halaman login merupakan halaman utama ketika semua aktor akan mengakses aplikasi dan diharuskan memasukkan username dan password. Sedangkan halaman profil berisi informasi profil dari user. Pada halaman profil terdapat tombol logout untuk keluar dari aplikasi. Halaman login dan halaman profil pada aplikasi M-Learning dapat dilihat pada Gambar 3.

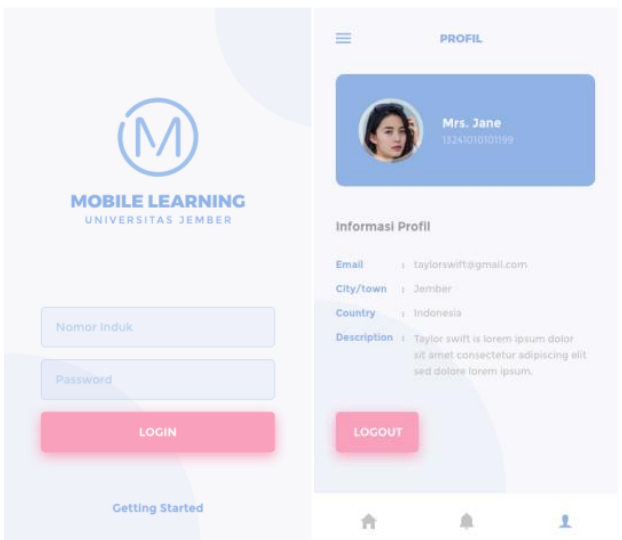

Gambar 3 Halaman Login (kiri) dan Halaman Profil (kanan)

Halaman beranda berisi daftar mata kuliah yang diambil pada semester tersebut. Setiap mata kuliah memiliki banyak kategori materi yang berisi materi-materi kuliah dan dapat dilihat pada halaman kategori materi kuliah Halaman beranda dan halaman kategori materi dapat dilihat pada Gambar 4.

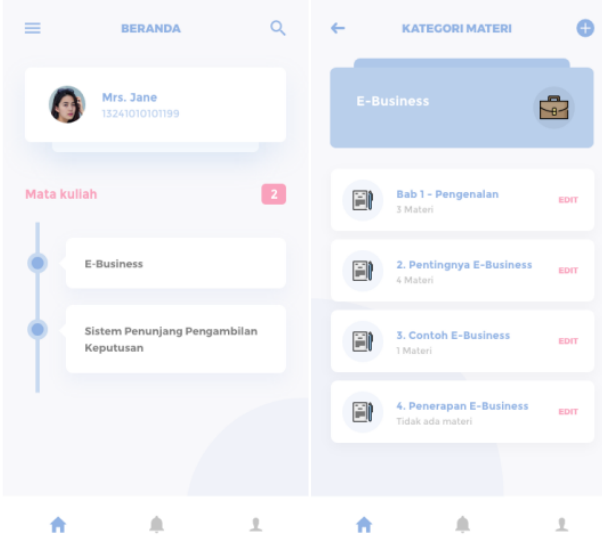

Gambar 4 Halaman Beranda (kiri) dan Halaman Kategori Materi (kanan) 
Halaman materi kuliah berada di dalam kategori materi kuliah. Tiap materi kuliah terdapat rincian yang terdapat pada halaman rincian materi. Halaman materi kuliah dan halaman rincian materi kuliah dapat dilihat pada Gambar 5.

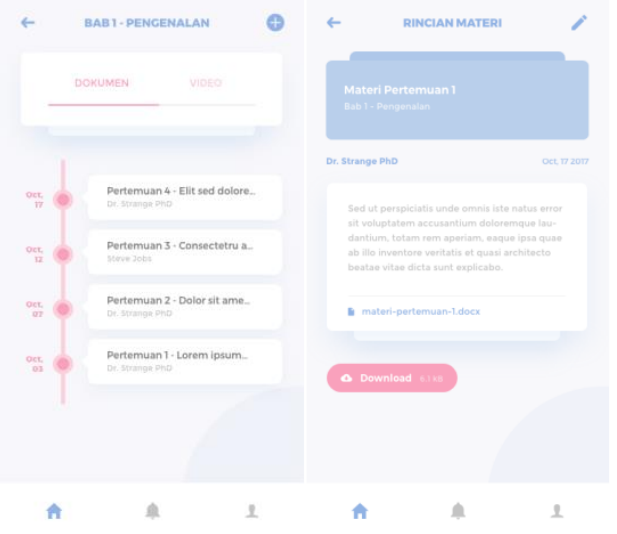

Gambar 5 Halaman Materi Kuliah (kiri) dan Halaman Rincian Materi (kanan)

Halaman materi video berada di dalam kategori materi kuliah. Tiap materi video terdapat rincian yang terdapat pada halaman rincian materi video. Halaman materi video dan halaman rincian materi video dapat dilihat pada Gambar 6.

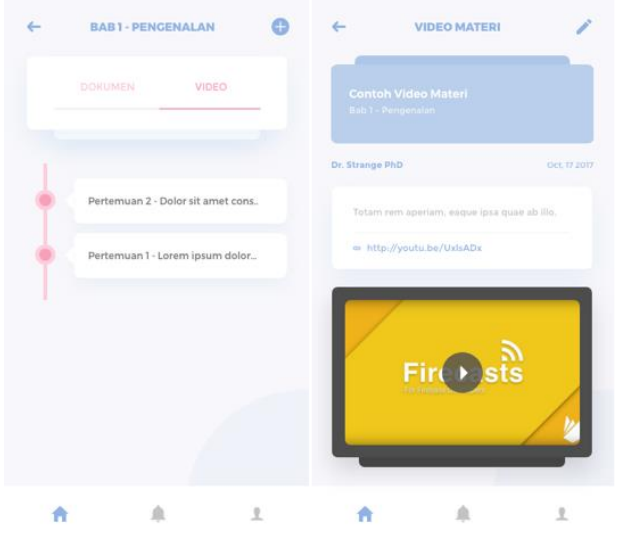

Gambar 6 Halaman Materi Video (kiri) dan Halaman Rincian Materi Video (kanan)

Halaman pengumuman berisi pengumuman yang diberikan oleh dosen mata kuliah kepada mahasiswa yang sedang mengambil mata kuliah tersebut. Di dalam pengumuman memuat rincian yang terdapat pada halaman rincian pengumuman.

\section{Kesimpulan}

Penerepan metode UCD dalam mengembangkan aplikasi M-Learning Universitas Jember dinilai mampu meningkatkan kenyamanan pada pengguna. Hasil kuesioner menunjukkan dari ke 5 variabel usability, 3 diantaranya (learnability, efficiency, memorability) mendapat penilaian yang kurang baik dan 2 lainnya mendapat penilaian yang cukup baik, sehingga diperlukan perbaikan bagi E-Learning Universitas Jember khususnya pada ke 3 poin tersebut. Penggunaan metode UCD memiliki konsep menjadikan user sebagai pusat dari perancangan aplikasi[12]. Sehingga pengguna (mahasiswa dan dosen) berperan dalam mencari masalah atau kekurangan yang terdapat pada E-Learning Universitas Jember melalui pengisian kuesioner dan menjadi tester pada proses usability testing.

Penggunaan usability testing dilakukan untuk menganalisa bagaimana user melakukan interaksi dengan prototype dari M-Learning yaitu menggunakan tabel Completion Rate untuk menilai keberhasilan user dalam menjalankan skenario pengujian yang diberikan[13]. Pada tabel completion rate ditemukan beberapa masalah yang merujuk pada sebuah rekomendasi perbaikan pada fitur rincian pengumuman. Sehingga memerlukan perbaikan prototype pada fitur tersebut dan dilakukan pengujian lagi sampai setiap tester dapat menyelesaikan semua tugas atau skenario pengujian yang diberikan dengan hasil baik sebagai indikasi bahwa pengguna telah merasa nyaman dengan tampilan tersebut. Penggunaan kedua metode ini saling mendukung 
dalam pembangunan M-Learning yaitu memperhatikan sisi kegunaan atau usability sehingga dapat meningkatkan kepuasan user atau pengguna saat menggunakan aplikasi.

\section{Daftar Pustaka}

[1] Bahtiar, A. (2013, May 30). Menuju Standarisasi Layanan E-Learning di Perguruan Tinggi. Bandung.

[2] Allen, M. (2013). Michael Allen's Guide to E-learning.

[3] Andriansyah, I. (2013). Eksplorasi Pola Komunikasi dalam Diskusi Menggunakan Moddle pada Perkuliahan Simulasi Pembelajaran Kimia,. Universitas Pendidikan Indonesia.

[4] Azwar. (1986). Reliabilitas dan Validitas: Interpretasi dan Komputasi. Yogyakarta: Liberty.

[5] Chandrawati, S. R. (2010). Pemanfaatan E-Learning dalam Pembelajaran. Universitas Tanjungpura.

[6] Jool, Soohyung, et.al . (Desember 2011). A Usability Evaluation Model. Journal of Library And Information Studies 9:2, 11-16.

[7] Khoirina, F. (2017). Evaluasi Web Usability Pada Modul Aplikasi Daftar Online Rumah Sakit Berdasarkan Nielsen Model dengan Metode User Testing dan Teknik Heuristic Evaluation (Studi Kasus: E-Health Rumah Sakit Umum Daerah Gambiran Kediri).

[8] Kuncoro, M. (2003). Metode Riset Untuk Bisnis Dan Ekonomi. Jakarta: Erlangga.

[9] Nielsen, J. (2012). Usability 101: Introduction to Usability. Retrieved from http:// www. nngroup. com/articles/usability-101-intro- duction-to-usability

[10] Nursalam, \& Efendi, F. (2008). Pendidikan dalam Keperawatan. Salemba Medika.

[11] Simatupang, R. M. (2014). Penerapan Metode User Centered Design Untuk Perancangan Aplikasi Radio Streaming Berbasis Web. Informasi dan Teknologi, Volume III 1-5.

[12] Sutoyo, A. (2009). Pemahaman Individu. Semarang: CV. Widya Karya.

[13] Zahara. (2013). Perancangan Aplikasi E-Commerce Penjualan Sparepart Forkflit dengan Metode UCD. 